\title{
The Challenge of Zoom Cloud Meeting in Online Learning Process
}

\author{
Indah Komsiyah ${ }^{1}$ \\ DOI: 10.35445/alishlah.v13i2. 820
}

\section{Article Info}

Keywords:

Learning;

Online;

Zoom Meeting

Kata kunci:

Pembelajaran;

Daring;

Zoom Meeting

\begin{abstract}
Online learning and teaching are some of the appropriate learning concepts during the current Covid-19 pandemic. This research aims to get in-depth information about the implementation of zoom cloud meetings in the online learning process. This evaluation is carried out to get a solution to the problem while using zoom cloud meeting. The study used a qualitative approach with a survey method. Data were collected through observation, interviews and questionnaires. The data analysis technique used the stages of reduction, data presentation, data analysis, and concluding. The results showed that the students had difficulties in providing internet networks. Students want each zoom activity to be more interactive and can be varied with other technology applications. In addition, students also need a balance between quota facilities, internet networks, a variety of other learning media and learning activities that suit student needs. The results of this study have implications for the development of online learning activities according to the ability of students' backgrounds.
\end{abstract}

\begin{abstract}
Abstrak
Pembelajaran dan pengajaran secara daring menjadi salah satu konsep belajar yang sesuai pada masa pandemic Covid-19 saat ini. Tujuan penelitian adalah untuk mendapatkan informasi mendalam tentang implementasi zoom cloud meeting dalam proses pembelajaran daring. Evaluasi ini dilakukan untuk mendapatkan penyelesaian masalah selama menggunakan zoom cloud meeting. Penelitian menggunakan pendekatan kualitatif dengan metode survey. Data dikumpulkan melalui observasi, wawancara dan kuesioner. Teknik analisis data menggunakan tahapan reduksi, penyajian data, analysis data, dan penarikan simpulan. Hasil penelitian menunjukkan bahwa para mahasiswa memiliki kesulitan dalam penyediaan jaringan internet. Mahasiswa ingin setiap kegiatan zoom lebih interaktif dan dapat divariasikan dengan aplikasi teknologi lainnya. Selain itu, mahasiswa juga membutuhkan keseimbangan antara fasilitas kuota, jaringan internet, variasi media belajar lain serta kegiatan belajar yang sesuai kebutuhan mahasiswa. Hasil penelitian ini berimplikasi pada pengembangan kegiatan belajar daring yang sesuai kemampuan latar belakang mahasiswa.
\end{abstract}

\footnotetext{
${ }^{1}$ Universitas Islam Negeri Sayyid Ali Rahmatullah Tulungagung, Indonesia Email: indahkomsyah@yahoo.com
} 


\section{INTRODUCTION}

The Covid-19 pandemic period has given many problems to changes in human life starting from the economic, social, educational and so on. The World Health Organization or WHO has stated that COVID-19 is a severe threat to all human life globally because this pandemic has stopped various activities globally. Critical conditions have hit education at universities or other educational institutions (Adedoyin \& Soykan, 2020). In the education sector, the government has issued an emergency policy for implementing education during the COVID-19 pandemic for elementary school to university levels. Face-to-face teaching is carried out online (Patricia Aguilera-Hermida, 2020). However, online learning is not easy to do because of the diversity of regions in Indonesia. Many problems arise during online learning activities. Students who come from different places raise different problems, such as the internet network (Meladina \& Zaswita, 2020). Online distance learning is described as a challenging experience that lacks efficient communication channels and fails to meet the particular needs of deaf children concerning communication media (Alshawabkeh et al., 2021)

In addition, problems originating from educators are also a significant consideration for educational institutions. They must prepare teaching and learning activities such as materials, learning media, and teaching strategies. In Chile, schools have proven the idea that the professionalism of the teaching staff must be continuously improved. This is, of course, related to the way they deal with the COVID-19 pandemic situation (González et al., 2020). Educators face enormous changes, such as adaptive and transformative for teaching and learning activities (Khanna \& Kareem, 2021). Even in developing or underdeveloped countries, such as Pakistan, students still find it challenging to access the internet, so learning activities are not always done online. It impacts reducing face-to-face interaction with teachers and causing problems in students' understanding of learning outcomes (Adnan, 2020).

The results of the analysis of observational data that have been carried out in 2020 in the Islamic Religious Education Study Program are related to online learning using various applications such as zoom. This application is a model for one technology application media that facilitates online teaching and learning activities. However, the application of these technologies faces various challenges and problems. Some of the problems that arise during online learning activities include 1) the level of awareness of students in exploring their abilities is deficient and tends to be passive when they zoom, 2) students often do not attend zoom activities due to internet network constraints, 3) not all students have sufficient internet quota to zoom, and 4) students tend to wait for assignments from the teacher and are less interactive during zooming. Therefore, problems that arise during zoom activities require periodic evaluations to overcome difficulties during online classes.

To get the right evaluation results, research is also needed to solve the problem of learning activities using zoom during 2020. Another reason for the urgency of this study activity to be carried out is the need for technology applications that can be used for teaching and learning activities according to student needs. Many studies have been conducted related to the application of technology for online learning activities. Skype and Zoom are quite good for learning conversation or speaking because they can display screens and be interactive in writing and orally (Cuaca Dharma et al., 2017). As a popular instant messaging software in China, WeChat has been widely adopted to support academic group discussions (Xu et al., 2020). Even educational practitioners have adopted social media for community and classroom groups (Shen et al., 2017). Massive open online courses (MOOCs) has offered the different concept of learning activity in online learning (Terras \& Ramsay, 2015). It can use video as the main component in MOOCs. However, the effectiveness of the video has not been tested to determine the effect on student learning outcomes (Hansch et al., 2015). Many teachers use pictures, videos and web conferences as a medium for teaching and learning (Suduc et al., 2012). Teachers have been creative in making video modules that contain learning topics as a form or medium for learning in class (Lancellotti et al., 2016; Lounek, 2015). 
From this research, it is known that the last research describes the role of technology in the process of providing education today. Therefore, this study focuses on evaluating the use of zoom in online teaching and learning in the Islamic Religious Education study program. It wants to find out how the challenges, difficulties and students' desires in using zoom for learning activities are. The research seeks to reveal gaps related to the implementation of zoom as multimedia in learning in the Islamic Religious Education Study Program how the difficulties faced by students in using zoom became the basis for evaluating the improvement of planning for the implementation of learning and teaching. So, the gap to be found is the accuracy of using zoom for the needs of students with various backgrounds, such as the ability to provide quotas, the economic capacity of students, and the existing network in each student area. With this evaluation, the study program can build multimedia according to the context of the University and students. So, this research aims to get in-depth information about the implementation of zoom cloud meetings in the online learning process. This evaluation is carried out to get a solution to the problem while using zoom cloud meeting. The research results are expected to be useful as a guide for evaluating activities using zoom cloud meetings or the use of appropriate technology applications for online classes in the Islamic Religious Education study program. In addition, research can be useful as a model or method of evaluating programs that have been used in university study programs so that solutions to any program deficiencies can be overcome or find the right solution.

\section{METHODS}

This study used a qualitative approach through the survey. It is used to collect the data from groups of the respondent to get the information. This methodology collects the data using some questions. This process comprises asking the respondent for information, such as using a questionnaire that can be used online or offline (Creswell \& Creswell, 2018). Participants of the study were students in the Islamic Religious Education study program in IAIN Tulungagung. They are $5^{0}$ students.

So, it explored the phenomenon of implementation of zoom cloud meeting in online learning. The data was collected using some methods, including;

a. Observation. It is used to know the process of teaching and learning in zoom cloud meetings. The researcher observes students' activity in an online class.

b. Interview. It used to know the students' perception about zoom cloud meeting in online learning. It did after class in each semester.

c. Questionnaire. It was distributed to students to find out the lacks, desires and needs of students to use Zoom cloud meeting technology applications. Here are the components of the questionnaire to analyze the implementation of zoom cloud meetings.

\begin{tabular}{|c|c|c|c|c|}
\hline & Component & Items & Yes & No \\
\hline 1 & Lacks & $\begin{array}{l}\text { 1. Do you have the technology tools to support online classes? } \\
\text { 2. Do you have a quota that can be used to zoom? } \\
\text { 3. Is the internet network at your home good for zooming? }\end{array}$ & & \\
\hline 2 & Desire & $\begin{array}{l}\text { 4. Do you always want to use zoom in every meeting? } \\
\text { 5. Do you want online classes with zoom to be more } \\
\text { interactive? } \\
\text { 6. Do you want to use other technology applications besides } \\
\text { zoom? }\end{array}$ & & \\
\hline 3 & Needs & $\begin{array}{l}\text { 7. Do you need a variety of online classes? } \\
\text { 8. Do you need a variety of other technology applications to } \\
\text { complement the use of zoom? } \\
\text { 9. Do you need other supporting learning media to use zoom, } \\
\text { such as video? } \\
\text { 10. Do you need a discussion via zoom combined with other } \\
\text { learning media? }\end{array}$ & & \\
\hline
\end{tabular}


Miles \& Huberman (1994) described the steps of data analysis. The first steps are data reduction refers to selecting, focusing, simplifying, abstracting, and changing the data collected from observations, interviews, and questionnaires. Then the data is transcribed according to the focus of the problem. The second is data display. The transcribed data is presented in the form of narrative text, diagrams or tables according to the analysis results. The data that has been analyzed is differentiated according to the findings to describe the systematic pattern of the application of Zoom cloud meetings technology, including findings of shortcomings, desires and needs of students. The third is conclusion drawing and conclusion. Concluding involves the previous stage to consider the suitability of the data findings with the focus of the problem. Verification is carried out by combining the concluding results so that the data findings can answer the research problem.

\section{FINDINGS AND DISCUSSION}

The result of data analysis from the questionnaire is presented in the following graph.

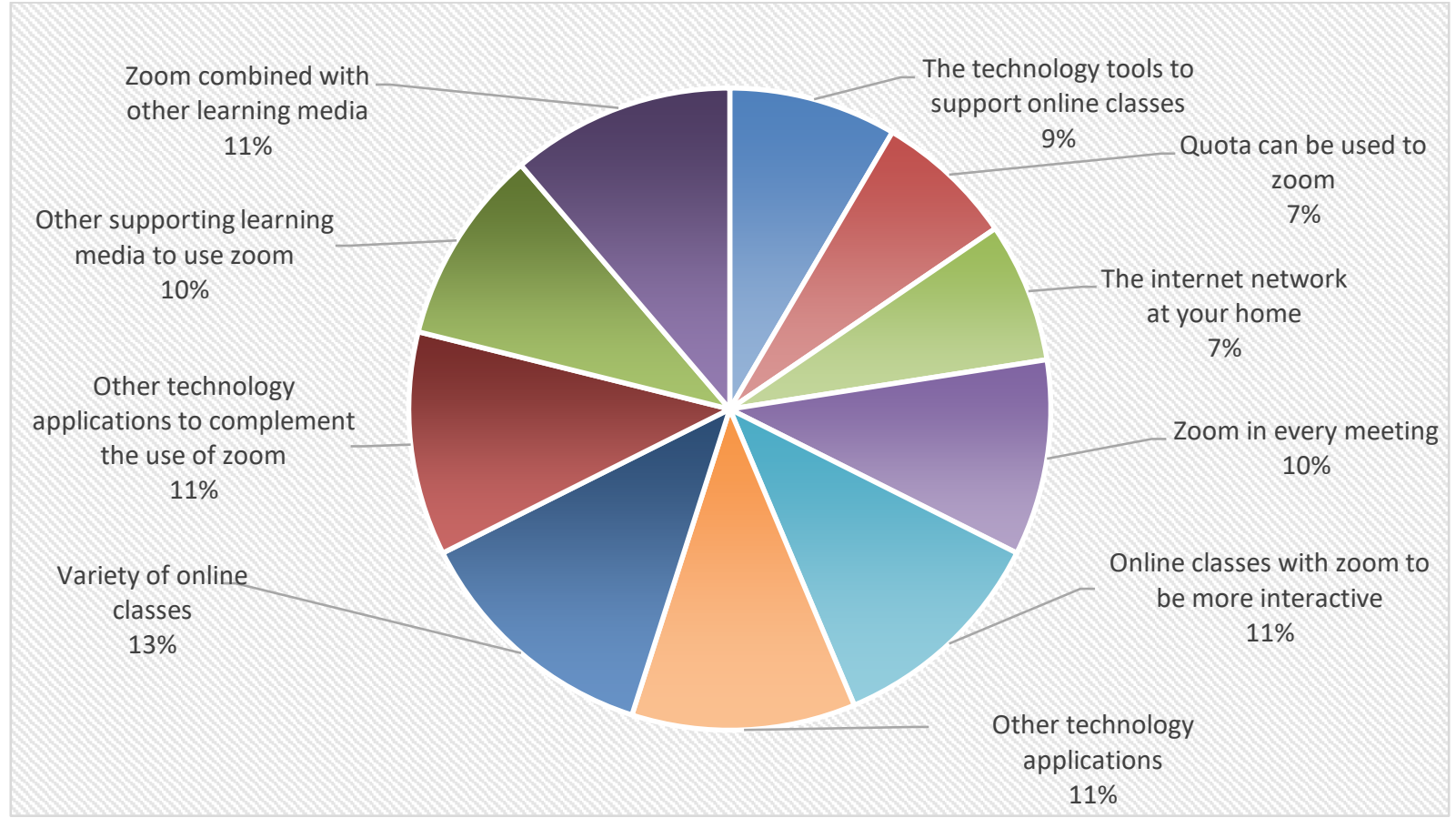

\section{Graph 1. Lacks/Desire/Needs of Online Learning Using Zoom}

Graph 1 is the result of distributing questionnaires related to the implementation of zoom cloud meetings in the Islamic Education Study Program. The results of data analysis show that the obstacles faced by students for online learning are technological devices, internet quotas and internet networks. Almost 50\% of the problems faced in online classes are quotas and internet networks. From the interview data, it is known that their parents are economically affected, so that it is difficult to provide a large enough quota. Parents find it challenging to provide quotas according to the needs of the learning process.

Moreover, there is more than one child who attends school. The students expect the use of other media in learning. From these findings, the study program must find the concept of online learning without having to use zoom in every meeting. Online learning activities cannot be avoided and carried out using the internet network (Marsap \& Narin, 2009). It means that educational institutions must incorporate or utilize technological advances for teaching and learning activities. There are various methodologies, contexts, and perspectives used to evaluate the use of technology in education. The use of instructional technology tends to focus on eight themes: learning outcomes, affective elements, behavior, design, technology elements, pedagogy, attendance, and institutional environment (Lai \& Bower, 2019). Currently, the internet is a productivity aid for learning activities 
that the government or educational institutions must carry out during the covid-19 pandemic. So, current technological advances have influenced the way humans acquire knowledge and carry out learning activities. The internet has provided easy access to information (Szymkowiak et al., 2021).

Students have the desire to zoom because the zoom learning process helps them understand the material more easily. The process of direct interaction can be done like offline learning activities. In addition, online learning activities do not only use zoom. Educators can take advantage of other technology applications such as Skype, Microsoft Team, YouTube, and so on (Hansch et al., 2015). Through well-known online communication media such as Skype and Zoom, online learning is increasingly popular (Cuaca Dharma et al., 2017). From the results of the interviews, it was concluded that students wanted online learning activities that could not be done completely every week with zoom. They could use videos uploaded to YouTube or animations that were shared on the website.

So the online learning process is not only done using videos. However, other multimedia access can provide convenience for students in learning during a pandemic. Such weblogs have a positive effect on learners by encouraging them to think critically. To compare the reflection of bloggers writing, four strategies were applied as follows: (a) blogging in groups without any additional feedback or influence, (b) blogging in groups with group friends' comments, (c) sharing ideas with group friends in the Sharing Corner in the weblog room before blogging individually in their group, and (d) creating a blog to reflect comments received by group mates. The results show that in promoting critical thinking, blogs are considered more effective than traditional writing, especially if the blogger accepts the comments of his group members (Hansch et al., 2015). A teacher can use a weblog to improve students' thinking and activity in religious material learning from this study. Umar \& Rathakrishnan (2012) use the Wiki online learning environment to work together to complete the tasks given in learning.

The research is in line with the findings, which conclude that the application of technology that can be combined makes it easier for students to complete assignments. Along with the questionnaire and interview data analysis results, it is known that students need various combinations of applications or technology devices that can be used in online classes. Thus, this study found an understanding of the concept of teacher professionalism in online teaching. This means that the current teacher's pedagogic abilities must be able to follow the development of science and technological progress. The results of the study also have implications for the concept of learning in the Islamic Religious Education study program, including:

1. The creativity of teachers in using technology applications must be adjusted to the background and abilities of students.

2. The study program must have an online learning model that is tailored to the needs of students, both from the provision of technological devices, quotas or internet networks.

3. The study program must also organize activities to improve the pedagogic competence of educators who can meet global needs.

4. The study program must organize activities for educators in making various online learning media.

\section{CONCLUSION}

This study concluded that zoom cloud meetings could not be used every week for online learning activities because of students' ability to provide different quotas. In addition, the network in each area is different, which makes it difficult for students to zoom. Students expect online learning activities to be carried out by combining various other technological applications such as websites, YouTube, or video animations that can be shared through websites or WhatsApp groups. Therefore, the results of this study provide an in-depth understanding of educators that creativity in the use of multimedia is essential and must be applied according to the background of students' abilities so that learning objectives can be achieved. 
This research is still limited to the evaluation of zoom cloud meetings that have been implemented in the classrooms of Islamic Religious Education study programs. So, the data obtained is still limited to the evaluation of online learning media that utilizes technology. So, this research can still be developed by evaluating learning outcomes that have used zoom or the creativity of educators in preparing learning materials or media. Therefore, this study recommends that universities carry out online learning activities regularly and provide the results of the performance evaluation to each educator. Thus, every educator can continue to develop pedagogic competencies that are closely related to digital competencies

\section{REFERENCES}

Adedoyin, O. B., \& Soykan, E. (2020). Covid-19 pandemic and online learning: the challenges and opportunities. Interactive Learning Environments, 1-13. https://doi.org/10.1080/10494820.2020.1813180

Adnan, M. (2020). Online learning amid the COVID-19 pandemic: Students perspectives. Journal of Pedagogical Sociology and Psychology, 1(2), 45-51. https://doi.org/10.33902/JPSP.2020261309

Alshawabkeh, A. A., Woolsey, M. L., \& Kharbat, F. F. (2021). Using online information technology for deaf students during COVID-19: A closer look from experience. Heliyon, 7(5), eo6915. https://doi.org/10.1016/j.heliyon.2021.e06915

Creswell, J. W., \& Creswell, J. D. (2018). Research Design: Qualitative, Quantitative, and Mixed Methods Approaches Fifth Edition. SAGE Publications Inc.

Cuaca Dharma, H. R., Asmarani, D., \& Dewi, U. P. (2017). Basic Japanese Grammar and Conversation e-learning through Skype and Zoom Online Application. Procedia Computer Science, 116, 267-273. https://doi.org/10.1016/J.PROCS.2017.10.055

González, Á., Fernández, M. B., Pino-Yancovic, M., \& Madrid, R. (2020). Teaching in the pandemic: reconceptualizing Chilean educators' professionalism now and for the future. Journal of Professional Capital and Community, 5(3-4), 265-272. https://doi.org/10.1108/JPCC-06-2020-0043

Hansch, A., Hillers, L., McConachie, K., Newman, C., Schildhauer, T., \& Schmidt, P. (2015). Video and Online Learning: Critical Reflections and Findings from the Field. SSRN Electronic Journal. https://doi.org/10.2139/ssrn.2577882

Khanna, R., \& Kareem, D. J. (2021). Creating inclusive spaces in virtual classroom sessions during the COVID pandemic: An exploratory study of primary class teachers in India. International Journal of Educational Research Open, 2-2, 100038. https://doi.org/10.1016/j.ijedro.2021.100038

Lai, J. W. M., \& Bower, M. (2019). How is the use of technology in education evaluated? A systematic review. Computers \& Education, 133, 27-42. https://doi.org/10.1016/J.COMPEDU.2019.01.010

Lancellotti, M., Thomas, S., \& Kohli, C. (2016). Online video modules for improvement in student learning. Journal of Education for Business, 91(1), 19-22. https://doi.org/10.108o/o8832323.2015.1108281

Lounek, J. (2015). Developing Creativity in Teaching Digital Video Courses at The Faculty of Informatics and Management. Procedia - Social and Behavioral Sciences, 186, 283-287. https://doi.org/10.1016/j.sbspro.2015.04.061

Marsap, A., \& Narin, M. (2009). The integration of distance learning via internet and face to face learning: Why face to face learning is required in distance learning via internet? Procedia Social and Behavioral Sciences, 1(1), 2871-2878. https://doi.org/10.1016/j.sbspro.2009.01.510

Meladina, M., \& Zaswita, H. (2020). Students' Readiness and Problems to Face Online Learning in Pandemic Era. Tamaddun, 19(1), 1-8. https://doi.org/10.33096/tamaddun.v19i1.66

Miles, M. B., \& Huberman, A. M. (1994). Qualitative Data Analysis; An Expanded Sourcebook. Sage Publication.

Patricia Aguilera-Hermida, A. (2020). College students' use and acceptance of emergency online learning due to COVID-19. International Journal of Educational Research Open, 1, 100011. https://doi.org/10.1016/j.ijedro.2020.100011 
Shen, C. W., Kuo, C. J., \& Ly, P. T. M. (2017). Analysis of social media influencers and trends on online and mobile learning. International Review of Research in Open and Distance Learning, 18(1), 1-224. https://doi.org/10.19173/irrodl.v18i1.2640

Suduc, A.-M., Bîzoi, M., Gorghiu, G., \& Gorghiu, L.-M. (2012). Digital Images, Video and Web Conferences in Education: A Case Study. Procedia - Social and Behavioral Sciences, 46, 4102-4106. https://doi.org/10.1016/j.sbspro.2012.06.207

Szymkowiak, A., Melović, B., Dabić, M., Jeganathan, K., \& Kundi, G. S. (2021). Information technology and Gen Z: The role of teachers, the internet, and technology in the education of young people. Technology in Society, 65, 101565. https://doi.org/10.1016/j.techsoc.2021.101565

Terras, M. M., \& Ramsay, J. (2015). Massive open online courses (MOOCs): Insights and challenges from a psychological perspective. British Journal of Educational Technology, 46(3), 472-487. https://doi.org/10.1111/bjet.12274

Umar, I. N., \& Rathakrishnan, M. (2012). The Effects of Online Teachers' Social Role and Learning Style on Students' Essay Writing Performance and Critical Thinking in a Wiki Environment. Procedia - Social and Behavioral Sciences, 46, 5730-5735. https://doi.org/10.1016/J.SBSPRO.2012.06.506

$\mathrm{Xu}, \mathrm{B}$., Chen, N. S., \& Chen, G. (2020). Effects of teacher role on student engagement in WeChatBased online discussion learning. Computers and Education, 157, 103956. https://doi.org/10.1016/j.compedu.2020.103956 